\title{
Technical, Field, Economic and Energy Comparison of Cutter Bar Maize Header With Snap Roll Maize Header
}

\author{
Surinder Singh Thakur ${ }^{1}$, Rupinder Chandel ${ }^{1} \&$ Manjeet Singh ${ }^{1}$ \\ ${ }^{1}$ Department of Farm Machinery and Power Engineering, Punjab Agrciultural University, Ludhiana, India \\ Correspondence: Rupinder Chandel, Department of Farm Machinery and Power Engineering, Punjab \\ Agrciultural University, Ludhiana 141004, India. E-mail: rupinder26@gmail.com
}

Received: April 5, 2020

Accepted: October 8, $2020 \quad$ Online Published: March 15, 2021

doi:10.5539/jas.v13n4p155

URL: https://doi.org/10.5539/jas.v13n4p155

\begin{abstract}
In India, most of the maize combine harvester currently being used employs snap roll type header. This type of header is costly, dependent on row spacing of maize crop and causes losses at headlands during turning. Moreover owing to its heavy weight its frequent lifting and downing during harvesting season causes hydraulic leakages in certain sections of combine. Therefore to overcome these problems a new light weight cutter bar Maize header is developed and evaluated for maize crop. The performance evaluation of the cutter bar type maize header is done in a dislodged and a partially lodged (30-40\%) maize crop. For lodged crops, the header losses varied from $19.18-26.71 \%$ and for dislodged crops it was varied from $5.29-10.15 \%$ respectively. The cylinder losses for dislodged crop varied from $2.70-2.86 \%$ and for lodged crop it varied from $0.85-2.04 \%$. The mean cleaning efficiency for lodged and dislodged maize crop was found as $88.87 \%$ and $90.58 \%$ respectively. The grain damage for lodged and dislodged crop was observed as $8.31 \%$ and $5.94 \%$ respectively. The trash content for lodged and dislodged crop was 2.75 and $3.45 \%$ respectively. The performance of snap roll and cutter bar was also done. Total losses with snap roll header were higher as $15.06 \%$ and lower for cutter bar as $10.85 \%$. The brokens were higher for cutter bar as 5.94 and lower for snap roll as $3.45 \%$. The trash content was $3.45 \%$ for cutter bar header and $2.24 \%$ for snap roll header. The total energy input in snap roll header, cutter bar maize header and maize dehusker cum sheller were 2360.05, 1970.90 and $3770.48 \mathrm{MJ} /$ ha respectively.The cost of operatin with cutter bar maize header, snap roll maize header and maize dehusker cum sheller were $53.62 \$ /$ ha, $68.73 \$ /$ ha $187.32 \$ /$ ha respectively.
\end{abstract}

Keywords: combine, snap roll header, cutter bar header, cylinder loss, harvester, header ear loss, maize, crop residues, yield components

\section{Introduction}

Losses while harvesting can be separated into three categories. Gathering losses that occur at the front of the combine consist of ears (missed or dropped by corn head) and kernels (shelled by the stalk rolls on the corn head). Threshing and separating losses are found on the ground behind the combine. Threshing losses are damaged kernels in the tank and kernels attached to the cobs that were not shelled by the combine rotor or cylinder. Separating losses are loose kernels that were not shaken out of the cobs and husks and were, subsequently, lost over the back of the combine (Humburg et al., 2009; Sumner \& Williams, 2009). Mechanisms to gather and cut the crop are located in the header, also called the cutting platform. Slat-type (bat) and pickup reels are commonly used for gathering small grain crops. Pickup reels are used for lodged crops (crops that have fallen over due to heavy rains, winds, etc.), as they have fingers that pick them up for cutting. Proper operation of the reel is critical to minimize header losses that include shatter losses and cutter bar losses. Both these losses are affected by cutter bar height, reel position with respect to the cutter bar, and reel peripheral speed, which is recommended to be about $25-50 \%$ faster than the forward speed of the combine (Behroozi-Lar \& Mobli, 2006). Grain losses induced from platform of the investigated combine gained $1.29 \%$ and losses at the back of the combine was $0.96 \%$. The most amount of damaged grains achieved $10.8 \%$ at the speed of $850 \mathrm{rpm}$ for the cylinder (Hassani et al., 2011). The header loss depends on reel rotational speed, ground speed and cutting bar knives. Reel rotational speed and ground speed are mostly efficacious and their losses are $0.5-2 \%$ of field yield components (Mazaheri, 1997). Crops with low height couldn't be cut by a cutter, as the seeds drop when they come in contact with the reel. Behroozi-Lar (1995) showed that the reel should be placed in $15-25 \mathrm{~cm}$ above the 
cutter bar; also, cutting height should be lower than lowest size of crop; furthermore, the reel speed should be adjusted about 1.25-1.50 of ground speed. Mansouri and Minaei (2003) studied the effect of forward speed on header loss and indicated that header loss intensified with an increase in ground speed. A study, using regression analysis model, was performed to estimate and predict the combine header loss at different adjustments of combine header. Three factors were considered as input variables and combine header losses were regarded as output variables. Model showed that the coefficient of determination $\left(r^{2}\right)$ is equal to 0.6292 (Abdi \& Jalali, 2013) Qarnar-uz-Zaman et al. (1992) showed that the losses increase with an increase in ground speed. Mostofi et al. (2011) found that the best ground speed for JD 995 was $1.32 \mathrm{~km} / \mathrm{h}$. Optimum operating condition of stripper header was obtained with a hood height of $75 \mathrm{~cm}$, header height of $60 \mathrm{~cm}$ and rotor speed of $760 \mathrm{rpm}$. In this condition, the average amount of unstripped loss (header and straw walker) and total loss respectively was 0.54 , 1.17 and $1.94 \%$ of yield, which indicated considerable decrease of grain losses according to conventional cutter-bar header loss. In all the experiments grain losses decreased with an increase in combine speed.

The results showed that power model was the best model to describe the dependence of the independent variables and the dependent variables. The optimum conditions for the minimum combine header loss (103 $\mathrm{kg} / \mathrm{ha}$ ), reel index, cutting height of crop and horizontal and vertical distances of reel from cutter bar were obtained $1.2 \mathrm{~cm}, 25 \mathrm{~cm}, 5 \mathrm{~cm}, 5 \mathrm{~cm}$ respectively (Zareei \& Abdollahpour, 2016). Relevant parameters and indicators were established according to the results of the investigations. Fuel consumption was obtained 14.04 1/ha, and $58.97 \mathrm{l} / \mathrm{ha}$ for maintaining an efficiency of $24.2 \mathrm{ha} / \mathrm{h}$ and an average working of speed $8.0 \mathrm{~km} / \mathrm{h}$. The utilization range of investigated harvesters was $70 \%$, with a considerable potential for improvement through better harmonizing of the working regime and the working conditions (Miodragovic \& Djevic, 2006). Sensitivity analysis revealed that cylinder speed was the most significant parameter in seed corn harvesting losses (Pishgar-Komleh et al., 2012). Though, harvesting losses cannot be eliminated, yet they can be decreased. Each kilogram of corn (or any other crops) that is saved by careful use of combine, adds to the profit derived from a cultivated hectare (Hanna \& Fossen, 1990). Some factors in combine harvester that can reduce corn losses are ground speed, header height, concave, cylinder or rotor speed and cleaning unit (Digman, 2009). So, achieving proper combine setting (ground speed, cylinder speed, cleaning airflow, snapping rolls and spacing between plates) (Hanna, 2008) can help increase combine efficiency, increase grain quality and minimize field losses. Although harvesting losses cannot be removed, they can be reduced to $63 \mathrm{~kg} \mathrm{ha}^{-1}$ in corn (Hanna \& Fossen, 1990). Several studies in this area, such as by Quick (2003) have established a hyperbolic relationship between grain damage and harvested yield for corn combines. He found a certain "sweet spot" where the harvested or bin yield was optimal under the given crop conditions. Corn picker field tests showed that ground speed and snapping roll adjustment are the most important factors determining picking losses (King et al., 1955). Morvaridi et al. (2008) analyzed the effect of ground speed and cylinder speed on corn harvester losses. Results indicated that the effect of cylinder speed was more significant on thresher loss as compared to the ground speed. The maximum total loss $(5 \%)$ was calculated at ground speed of $2.23 \mathrm{~km} \mathrm{~h}^{-1}$ with the cylinder speed of $550 \mathrm{rpm}$. The experimental research has substantiated that a variable radius concave with a working plane tilt angle of the oblique concave crossbar equal to $45^{\circ}$ would be the rational option for corn ear threshing. In this case, the threshing losses of the grains were minimal $(0.03 \pm 0.01 \%)$, and the maximum share of grains damaged in the threshing unit do not exceed 4\% (Pužauskas et al., 2016). Harvest losses were determined for combines harvesting soybean and corn in Brazil. Total soybean combine losses ranged from 47.4 to $260.5 \mathrm{~kg} / \mathrm{ha}$ ( $1.2 \%$ to $5.5 \%$ of yield). The headers were the largest contributors to losses with 31 to $247 \mathrm{~kg} / \mathrm{ha}$. Total corn combine losses ranged from 36.2 to $320.6 \mathrm{~kg} / \mathrm{ha}$ ( $0.3 \%$ to $3.6 \%$ of yield). Of this loss, header ear loss accounted for the largest portion with 0 to $237 \mathrm{~kg} / \mathrm{ha}$. Shatter losses were the primary cause of losses in the headers. Also, they increased markedly as harvest moistures decreased below 13\%. Lodged corn can increase header ear losses as compared with any other source of loss (Paulsen et al., 2014). Threshing, separating and cleaning losses for well-trained combine operators can be very low, rice $0.3 \%$, maize $0.4 \%$, soybeans $0.75-1 \%$, and wheat $1 \%$ of yield or less. Losses will go higher when the header is included but in general, rice should be less than $1.25-2.2 \%$, maize less than $1.8 \%$, soybeans less than $3 \%$, and wheat less than $2 \%$ of yield in good standing crop (Paulsen et al., 2015). Till present from all the review cited, header plays an important role in minimizing shattering and cutterbar (i.e., header) losses. In most maize predominant areas, only snap roll headers are used in maize harvesting, which is highly dependent on row to row spacing of maize crop leading to higher losses during turnings, improper snap roll spacing and due to operator skill also. Moreover higher cost of snap roll header makes it unfeasible for small and marginal farmers. Therefore a new type of cutter bar type maize header was designed and developed for harvesting of maize crop which cuts the maize plant from a certain height (adjustable) and feeds plant along with cob to the threshing unit of the combine. The maize header was capable of cutting the maize crop, irrespective of the width of the row. The present study was focused to design develop a low cost 
cutter bar maize header and investigate its performance for both dislodged and partially lodged maize crop and its economic evaluation with snap roll header and maize dehusker cum sheller in Indian conditions.

\section{Method}

\subsection{Cutter Bar Header Development and Experimental Layout}

A first prototype of cutter bar type header with square section reel for maize crop harvester was designed and developed (Figure 1) by the Department of Farm Machinery and Power Engineering, Punjab Agricultural University, Ludhiana, India in collaboration with M/s Nirmal Mechanical Works, Moga, Punjab, India.

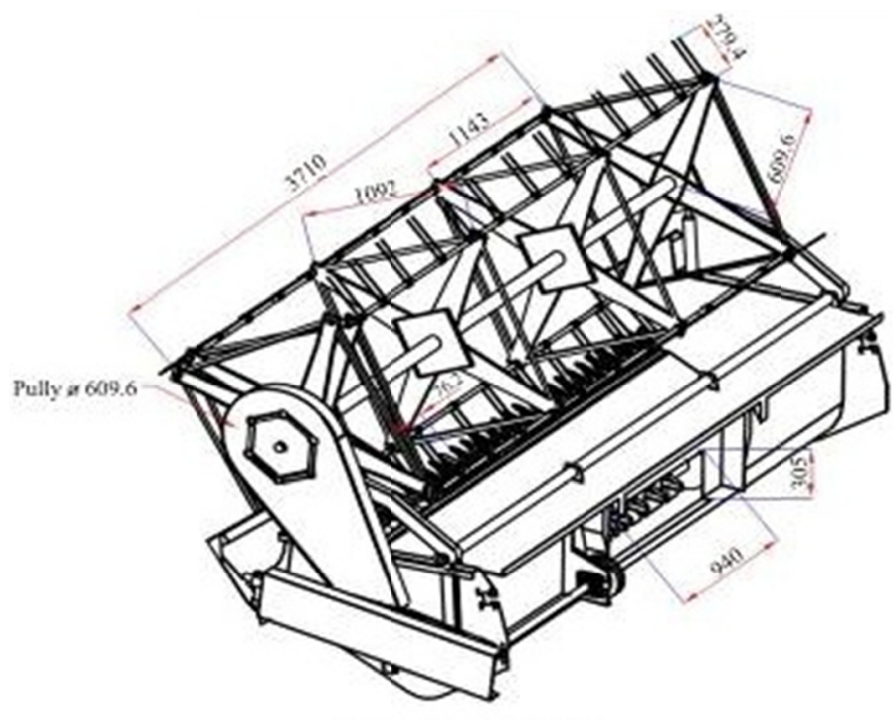

All Dimensions in $\mathrm{mm}$

Figure 1. A line diagram of cutter bar type maize header

In this header the conventional cutter bar was used, but with extended fingers. The extended fingers were provided to overcome the thrust coming from maize crop stalk. The fingers were made of mild steel and were tempered to give a greater strength. The reel section was made of mild steel with four sections. The square section reel with spring tines was provided. The reel was made of square section and was bigger in size. The tines were provided in staggered manner, so as, to efficiently collect the cut maize stalk with cobs and minimize the gathering losses. The drive to reel was provided mechanically through belt drive. After initial trials the sizes of driven pulley and pulley driving reel were selected, so as, to reduce the rpm of reel as compared to forward speed of combine. The auger was made of hot rolled sheet. The auger was driven through chain drive and spikes were provided in the middle in a staggered pattern, so as to create a positive feeding action of cut plants towards auger cylinder. The reel was lighter than the conventional snap roll header. The provision was given to adjust height of cut and reel height hydraulically. The crop after being harvested along with maize cobs was conveyed towards auger by a square section reel in a cutter bar header. The detailed specifications of cutter bar type maize header and combine are given in Tables 1 and 2 and a view of cutter bar header and its parts are shown in Figures 2 and 3. 

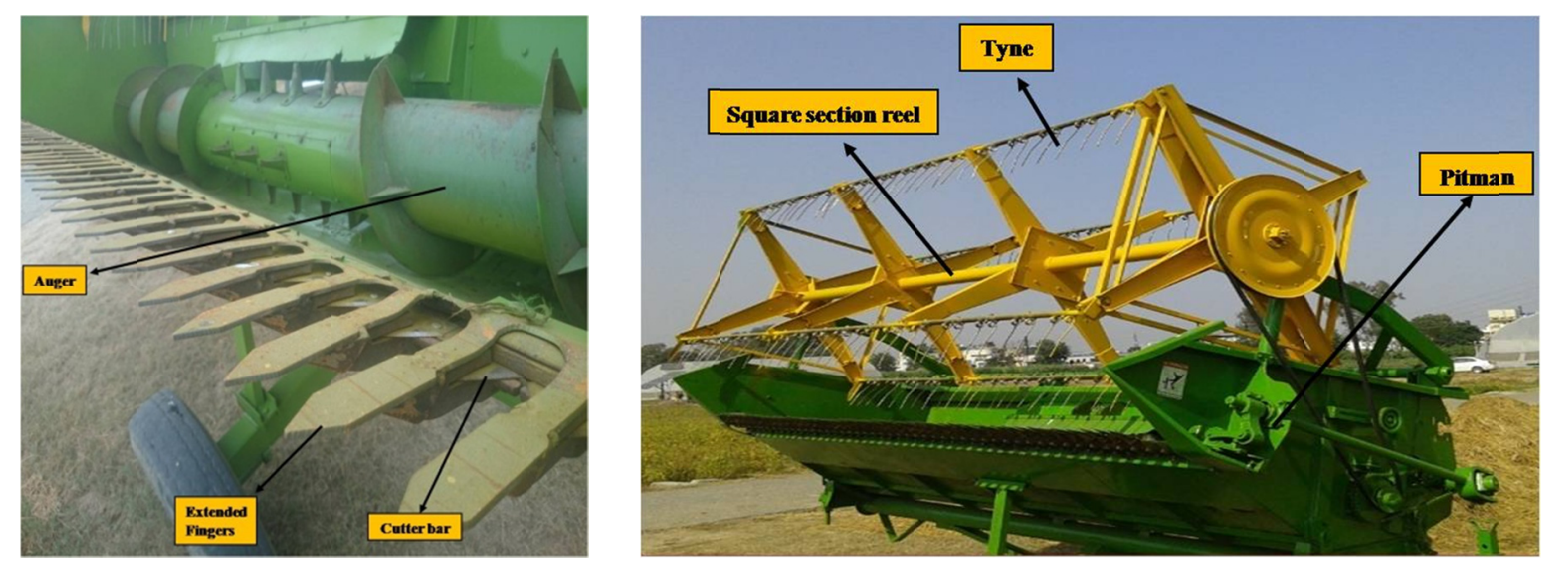

Figure 2. View of developed cutter bar header and extended fingers and auger drum
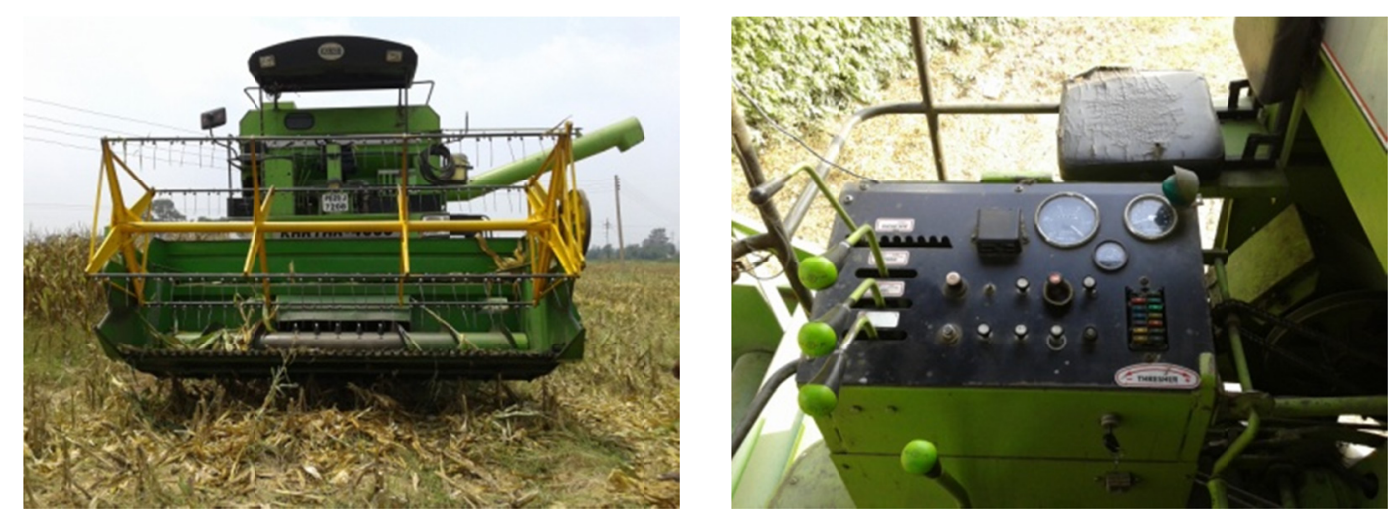

Figure 3. View of developed cutter bar header and control unit of combine harvester 
Table 1. Specifications of cutter bar type maize header

\begin{tabular}{|c|c|c|}
\hline Particulars & Specifications of cutter bar type header & Material of parts \\
\hline Width of header, mm & 3710 & - \\
\hline Total no. of blades on cutter bar & 48 & High carbon steel \\
\hline Cutter bar height adjustment & Hydraulic & - \\
\hline Cutter bar height adjustment range, $\mathrm{mm}$ & $0-1524$ & - \\
\hline Extended Finger length, mm & 254 & Tempered mild steel \\
\hline Finger to finger spacing, $\mathrm{mm}$ & 76.2 & - \\
\hline \multirow[t]{2}{*}{ Reel type } & Pick up & Mild steel \\
\hline & & Nylon bush at ends $-35 \mathrm{~mm}$ \\
\hline Reel section and side, $\mathrm{mm}$ & Square, 1168.40 & - \\
\hline Number of spokes on each square section and length, $\mathrm{mm}$ & 4, 609.60 & Mild steel \\
\hline Tine length, mm & 279.40 & Spring wire \\
\hline Number of tines between two consecutive square sections & 10 & - \\
\hline Tine arrangement on consecutive bars & Staggered or alternative. & - \\
\hline Reel speed adjustment & Mechanical & - \\
\hline Reel height adjustment & hydraulic & \\
\hline Reel height adjustment range, $\mathrm{mm}$ & $38.1-914.4$ & \\
\hline Spacing between cutter bar and reel, $\mathrm{mm}$ & 508 & - \\
\hline Auger window, mm & $940 \times 305$ & \\
\hline Auger diameter, mm & 355.60 & Hot rolled sheet \\
\hline Auger bearing at ends & & UCF 207 (2) \\
\hline Auger lugs length, mm & 114.30 & \\
\hline Spacing between spokes & 203.2 & \\
\hline Driving pulley size, $\mathrm{mm}$ & 101.60 & SG Cast iron \\
\hline Driven pulley size, $\mathrm{mm}$ & 609.60 & SG Cast iron \\
\hline Centre to centre spacing between pulleys, $\mathrm{mm}$ & 1371.60 & - \\
\hline Distance between centre of driven pulley and crop divider edge, $\mathrm{mm}$ & 609.60 & - \\
\hline Length of platform section, $\mathrm{mm}$ & 584.2 & Mild steel \\
\hline Length of crop divider edge from cutter bar, $\mathrm{mm}$ & 685.80 & Mild steel \\
\hline Weight, $\mathrm{Kg}$ & 1200 & - \\
\hline
\end{tabular}


Table 2. Brief specifications of combine used in field experiments

\begin{tabular}{|c|c|}
\hline Different systems of combine & Specifications \\
\hline Model & Ashok Leyland \\
\hline Engine Power, Kw (at 2200 RPM) & 78.33 \\
\hline No. of Cylinder & Six \\
\hline Air Cleaner & Combination of Dry \& Wet Type \\
\hline Cooling System & Water Cooled \\
\hline \multicolumn{2}{|l|}{ Clutch } \\
\hline Type of Clutch & Single, Heavy Duty Dry Clutch \\
\hline Diameter, mm & 310 \\
\hline \multicolumn{2}{|l|}{ Transmission } \\
\hline No. of Gears & 3 Forward, 1 Reverse \\
\hline Forward Gear Speeds, $\mathrm{km} \mathrm{h}^{-1}$ & $\mathrm{~L}, \mathrm{H}$ \\
\hline 1st Gear & 2,4 \\
\hline 2nd Gear & 4,8 \\
\hline 3rd Gear & 8,20 \\
\hline Reverse Gear & 4,8 \\
\hline \multicolumn{2}{|l|}{ Threshing Mechanism } \\
\hline Threshing Cylinder Type & Rasp Bar Type \\
\hline No. of Rasp Bar and Spikes & 8,152 \\
\hline Diameter, mm & 606 \\
\hline Width, mm & 1250 \\
\hline Speed, rpm & $540-1200$ \\
\hline Speed Adjustments & By Means of Mechanical Variator \\
\hline \multicolumn{2}{|l|}{ Concave } \\
\hline Grate Size, $\mathrm{mm}$ & $35 \times 16$ \\
\hline Clearance, $\mathrm{mm}$ & Front-24, Rear-17 \\
\hline Adjustment & Mechanical \\
\hline \multicolumn{2}{|l|}{ Cleaning Sieves Area, $\mathrm{m}^{2}$} \\
\hline Upper Sieve & 2.47 \\
\hline Lower Sieve & 1.70 \\
\hline Grain Tank, $\mathrm{m}^{3}$ & 2.60 \\
\hline Fuel Tank Capacity, ltr & 365 \\
\hline No. of Batteries & 2 \\
\hline Capacity and Rating of Each, V, Ah & 12,88 \\
\hline Tyre & Size, Ply Rating \\
\hline Front & $18.4 / 15 \times 30,12 / 14$ \\
\hline Rear & $9.00 \times 16,16$ \\
\hline \multicolumn{2}{|l|}{ Main Dimensions (in working, $\mathrm{mm}$ ) } \\
\hline Length & 8370 \\
\hline Width & 3800 \\
\hline Height & 3800 \\
\hline Ground Clearance & 340 \\
\hline \multicolumn{2}{|l|}{ In Transport, $\mathrm{mm}$} \\
\hline Length, $1, \mathrm{~mm}$ & 12280 \\
\hline Width, b, mm & 3045 \\
\hline Height, h, mm & 3800 \\
\hline
\end{tabular}

Maize crop was sown at a research farm of Department of Farm Machinery and Power Engineering and at Farmer's fields during 2014, 2015 and 2016. Maize varieties PMH-2, Pioneer-1844, DKC-9108 was taken for the present study. Maize crop was sown at a recommended spacing of $0.60 \mathrm{~m} \times 0.20 \mathrm{~m}$ in experimental plots. The mean stalk height, girth and weight varied between $2.00-2.29 \mathrm{~m}, 49.23-60.30 \mathrm{~mm}$ and $9.58-11.52 \mathrm{Mg} \mathrm{ha}^{-1}$ and mean grain yield varied between $6.29-7.02 \mathrm{Mg} \mathrm{ha}^{-1}$ [at $21 \%$ m.c. (w.b.)] for different experimental plots. The mean cob outer diameter with husk varied between $42.74-44.68 \mathrm{~mm}$. To study the effect of header on various losses, cutter bar type header was tested on the standing and partially lodged maize crop (Figure 3) at the 
experimental plots of Department of Farm Machinery and Power Engineering, PAU, Ludhiana and at farmer's fields during 2014, 2015, and 2016. Combine had self propelled engine of $78.33 \mathrm{~kW}$ and a rasp bar type threshing cylinder with diameter and width as $606 \mathrm{~mm}$ and $1250 \mathrm{~mm}$ respectively (Table 3). The overall width of combine was $3800 \mathrm{~mm}$ and an effective width of cut was $3000 \mathrm{~mm}$. Effective width of maize header was calculated by measuring the average distance between the centre lines of adjacent picking units multiplied by the number of units. Firstly combine header and combine was checked for all repair and maintenance. Combine was also adjusted according to the cutter bar type maize header. Before operating the combine harvester in the field, by collecting samples from different locations, total grain yield was recorded in the field. The pre-harvest losses were also measured. Combine was operated along the longer length of the field. After operating the combine in the field, various data samples were collected to calculate the gathering losses, unthreshed losses and grain quality parameters like cleaning efficiency, grain damage, trash content etc. In this header ears were fed into the threshing unit along with the stalk. The crop and operational parameters like moisture content, reel operational rpm, threshing cylinder rpm, combine forward speed width of cut, height of cut, fuel consumption etc. were measured.

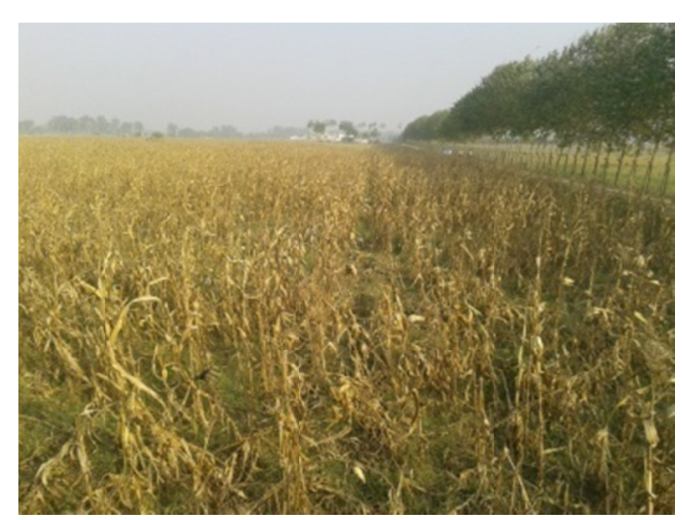

Figure 4. A view of experimental plot of lodged maize crop

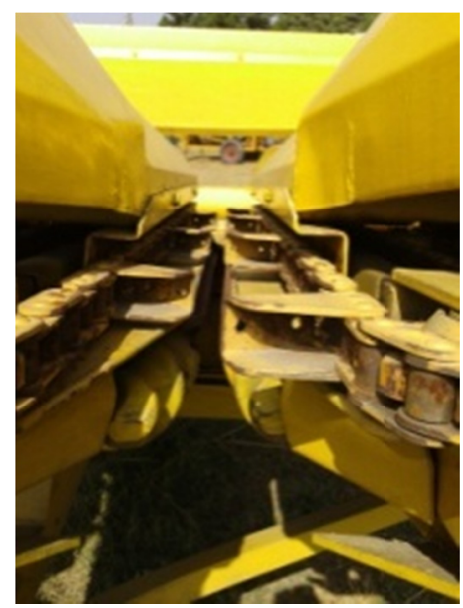

Figure 6. Snap roll

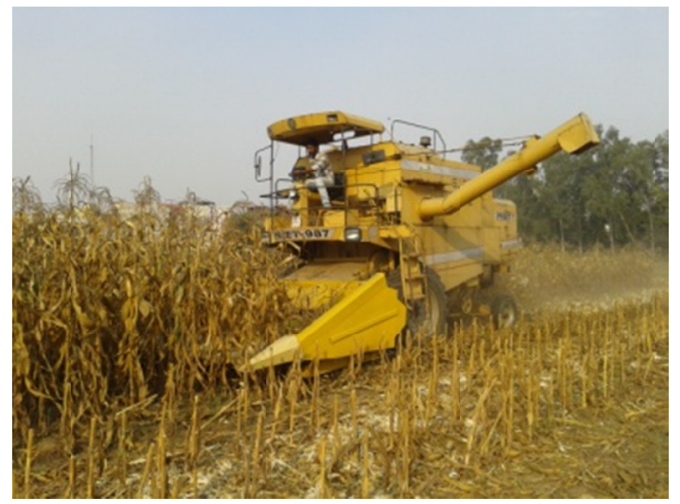

Figure 5. A view of maize harvesting with combine equipped with snap roll maize header

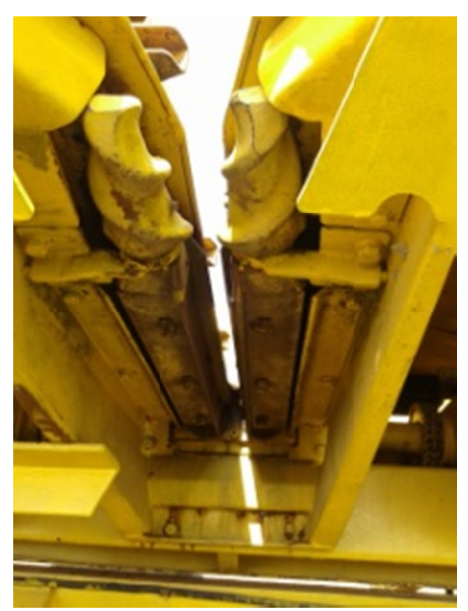

Figure 7. Chain conveyor 


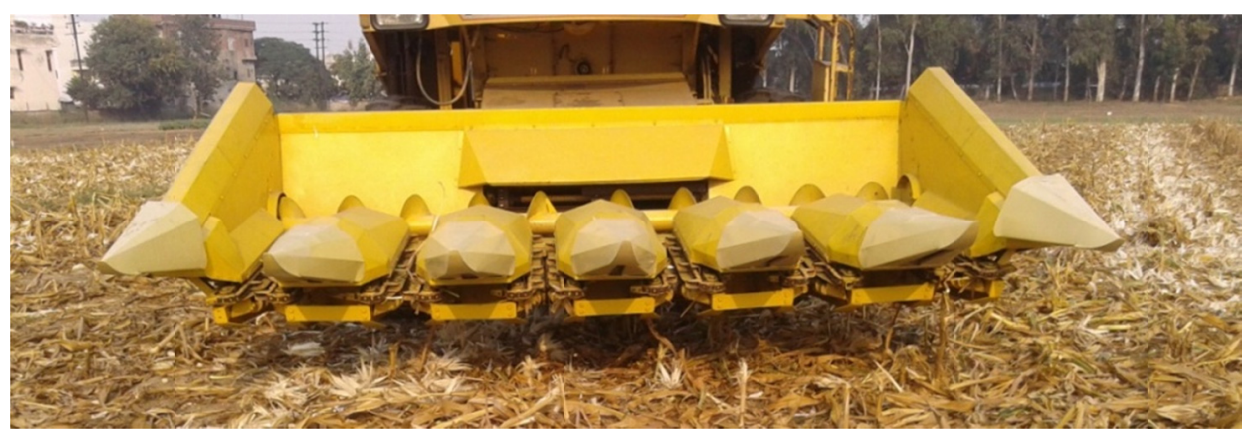

Figure 8. A view of snap roll type maize header

The 6 row snap roll maize header combine (Figure 8) was used for comparison with cutter bar maize header. The maize harvester with snap roll header was operated in maize crop (Figure 5). The view of field with lodged crop is shown in Figure 4 and snap roll and chain conveyor are shown in Figures 6 and 7. Specifications of snap roll maize header used are given in Table 4.

Table 4. Specifications of snap roll type maize header

\begin{tabular}{ll}
\hline Particulars & Specifications of snap roll type header \\
\hline Width of header, $\mathrm{m}$ & 3.60 \\
Spacing between crop dividers, mm & 600 \\
No. of rows & 6 \\
Total no. of blades & 12 \\
Spacing between cutter bar and reel/Number of cutter blade per snap roll & 4 (fitted $90^{\circ}$ to each other) \\
Auger window, mm & $1295 \times 330$ \\
Weight, $\mathrm{Kg}$ & 1,860 \\
\hline
\end{tabular}

\subsection{Equipment and Measurement}

\subsubsection{Digital Moisture Meter}

The specifications of digital moisture meter used to measure grain moisture content are given in Table 5 .

Table 5. Specifications of digital moisture meter (direct reading type) (Model No. AG-72)

\begin{tabular}{ll}
\hline Range & $3.5 \%-40 \%$ \\
Principle & Resistance Measurement \\
Accuracy & $\pm 0.2 \%$ \\
Display & Three Seven Segment Displays \\
Weight & $9.5 \mathrm{Kg}$ Approx. Without Accessories \\
Dimensions & $30 \times 17 \times 26$ cms Approx. \\
Power & Six $9 \mathrm{~V}$ Dry Cells or 230 volts, $50 \mathrm{~Hz}$ AC Through Adopter \\
Temperature & Automatic \\
\hline
\end{tabular}

Stop watch was used to measure the forward speed of the combine. Measuring tape was used to measure the dimensions of the field. For different losses, a cloth was used to collect the samples from different locations of the field. Weighing balance was used to measure the weight of threshed grain, unthreshed grain and straw of maize crop.

\subsubsection{Weighing Machine}

The weighing of grains and biomass was done using an electronic weighing balance. For measuring plot dimension a tape was used. The unthreshed cobs and shattered ears from the field were handpicked.

For measuring the header losses, cobs were collected from the field in $3 \times 3 \mathrm{~m}^{2}$ area at the different locations in the field. Grains were then collected from the cobs and were weighed to calculate the loss. 


\subsubsection{Field Operational Parameters Forward Speed, Reel rpm and Width of Cut}

At different moisture contents maize crop was harvested. The operational speed of machine was calculated as:

$$
v=3.6 \times S / T
$$

where, $\mathrm{v}$ is operational speed, $\mathrm{km} \mathrm{h}^{-1} ; S$ is distance covered in meter and $T$ is time taken in seconds.

Tachometer (Line seiki made) was used to measure operational reel rpm during field operation (Table 6 and Figure 9).

Table 6. Specifications of tachometer

\begin{tabular}{ll}
\hline Model & TM-5000 \\
Make & Line seiki \\
Measuring Range & $6.0-99999.9 \mathrm{r} / \mathrm{min}$ \\
Resolution & $0.1 \mathrm{r} / \mathrm{min}$ \\
Accuracy & $\pm 0.01 \% \pm 1$ digit r/min, $\mathrm{m} /$ min (for other units, the conversion accuracy is $\pm 0.05 \% \pm 1$ digit) \\
Sampling Time & $1.0-10.0$ seconds \\
Display & Display: 6 digits, 7 segment LCD \\
& Battery alarm: mark \\
& Reflective light: $((($ mark \\
& Display unit: r/min \\
Auto Power-Off & After 3 min from last measurement or key operation \\
Data Hold Time & Measurement data: until the next data is defined \\
& - \\
Measuring Method & Non-contact measurement using the main unit or with remote sensor (use with reflective tape) \\
& Contact measurement using the in-contact adaptor (use with rubber tip, surface speed wheel) \\
Measuring Distance & 50300 mm (using reflective tape) \\
Power Supply & 4 pcs. of AAA alkaline battery (continuous measurement of 20 hrs.) \\
Operating Temp. & $5-40{ }^{\circ} \mathrm{C}($ Non-freezing) \\
Storage Temp. & $-10-60{ }^{\circ} \mathrm{C}$ (Non-freezing) \\
Storage Humidity & $35-85 \%$ RH (Non-condensing) \\
Dimension/Wight & $122(\mathrm{H}) \times 58$ (46) $($ W) $\times 28$ (D) mm/Approx. $130 \mathrm{~g}$ (including batteries) \\
\hline
\end{tabular}

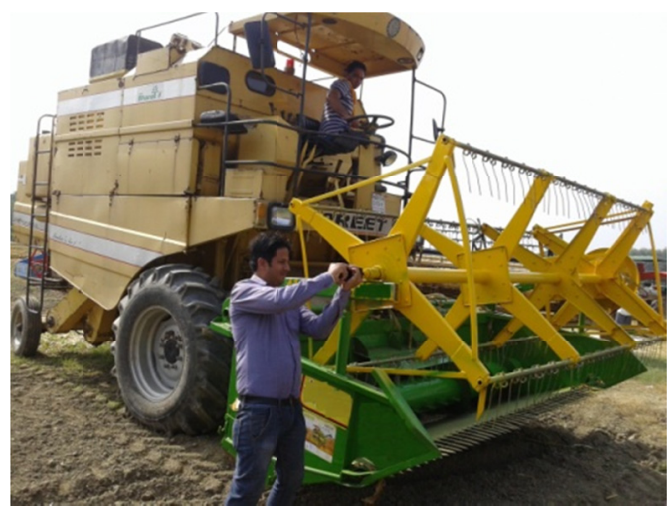

Figure 9. Measurement of reel rpm with tachometer at various engine speeds

Note. The width of cut was measured using a measuring tape.

\subsection{Estimation of Field Capacity and Various Losses Measurement}

The effective field capacity was determined by measuring all the time elements involved while harvesting. The total time was categorized into the productive and non-productive time. The productive time is the actual time used for harvesting the grains while the non-productive time consisted of the turning time, repair and adjustment time and other time losses. The area covered divided by the total time gave the effective field capacity. The effective field capacity of combine was calculated using the following formula (Kepner et al., 1978): 


$$
C=\frac{S W}{10} \times \frac{E_{f}}{100}
$$

where, C: effective field capacity, ha $\mathrm{h}^{-1} ; \mathrm{S}$ : speed of travel, $\mathrm{km} \mathrm{h}^{-1}$; W: rated width of implement, m; Ef: Field efficiency, in percent.

$$
E_{f}=100 \frac{T_{0}}{T_{e}+T_{h}+T_{a}}
$$

where, $\mathrm{T}_{0}$ : theoretical time per hectare (per acre); $\mathrm{T}_{\mathrm{e}}$ : effective operating time $=\mathrm{T}_{0} \times 100 / \mathrm{K}$; K: percent of implement width actually utilized; $\mathrm{T}_{\mathrm{h}}$ : time lost per acre due to interruptions that are not proportional to area. At least part of $\mathrm{T}_{\mathrm{h}}$ usually tends to be proportional to $\mathrm{T}_{\mathrm{e}} ; \mathrm{T}_{\mathrm{a}}$ : time lost per acre due to interruptions that tend to be proportional to area.

\subsubsection{Estimation of Fuel Consumption}

Before starting the test, the engine's fuel tank was completely filled. The quantity of fuel required to fill the tank after harvesting the test field was measured using a 11 graduated cylinder. Thus, the fuel consumed during the test was determined.

$$
F=L / A
$$

where, $\mathrm{F}$ is the fuel consumption in $1 \mathrm{ha}^{-1}$; $\mathrm{A}$ is the area harvested in ha; and $\mathrm{L}$ is the quantity of fuel required to fill the tank after harvesting the test field in 1.

\subsubsection{Caluclulations of Various Losses and Grain Quality Parameters in Combine Operation}

\section{(1) Header Ear Loss}

For measuring header losses, data for fallen cobs and kernels in front of machine where the separator had not yet passed. The combine was backed off by a distance equal to length of combine. Loose kernels, broken and whole cobs were gathered from this front area $(\mathrm{w} \times 1)$. These were gathered to calculate the header losses. The header ear losses were calculated as

$$
\text { Header ear loss, }(\%)=\frac{\text { Weight of grains }[\text { Loose and from fallen cobs }(\mathrm{kg})]}{\text { Total grain yield }(\mathrm{kg})} \times 100 \%
$$

(2) Cylinder Loss and Grain Quality Parameters

For measuring cylinder loss kernels still attached to the threshed cobs were collected from 1/100 acre area and weighed. The small kernels at the butt and tip end of cobs were not taken.

The loss of grains and ears which are left unthreshed by the combine over a unit area.

$$
\text { Cylinder loss, }(\%)=\frac{\text { Weight of grains, unthreshed left on ground }(\mathrm{kg})}{\text { Total grain yield }(\mathrm{kg})} \times 100 \%
$$

After the operation, samples weighing $200 \mathrm{~g}$ of grains were collected from the grain tank of the combine. These samples were then cleaned to get the trash content, broken grains and clean grains.

$$
\begin{gathered}
\text { Grain damage, }(\%)=\frac{\text { Weight of broken grains }(\mathrm{kg})}{\text { Weight of original sample }(\mathrm{kg})} \times 100 \% \\
\text { Cleaning efficiency, }(\%)=\frac{\text { Weight of clean grains }(\mathrm{kg})}{\text { Weight of original sample }(\mathrm{kg})} \times 100 \% \\
\text { Trash content, }(\%)=\frac{\text { Weight of trash }(\mathrm{kg})}{\text { Weight of original sample }(\mathrm{kg})} \times 100 \%
\end{gathered}
$$

\subsection{Energy Calculations}

Following equations were used for energy calculations in maize combine harvester with various headers:

Human energy consumption $(\mathrm{MJ} / \mathrm{ha})=$ No. of human labour used $\times$ Time $(\mathrm{h}) \times$ Human energy equivalent $(\mathrm{MJ} / \mathrm{h}) /$ Area covered (ha);

Fuel energy consumption $(\mathrm{MJ} / \mathrm{ha})=$ Fuel consumption $(\mathrm{l} / \mathrm{h}) \times$ Fuel energy equivalents $(\mathrm{MJ} / \mathrm{l}) /$ Effective field capacity (ha/h);

Enrgy embodied in machinery $(\mathrm{MJ} / \mathrm{ha})=$ Weight of specific machine $(\mathrm{kg}) \times$ Energy equivalent of machinery $(\mathrm{MJ} / \mathrm{kg}) /$ Wear out life of machine $(\mathrm{h}) \times$ Effective field capacity $(\mathrm{ha} / \mathrm{h})$. 


\subsection{Economics}

The economics of maize crop harvesting was also calculated for cutter bar header in comparison to the snap roll maize header and maize dehusker cum sheller.

\subsection{Statistical Analysis}

The software CPCS1 was used for statistical analysis of various treatments of field experiments conducted in present study. The maize combines were operated with snap roll header and cutter bar maize header and experiments were replicated and then statistical analysis was done.

\section{Results and Discussion}

The maize yield, grain moisture content and pre-harvest losses were measured prior to combine operation and are shown in Tables 7 and 8. The cutter bar maize header was operated in both dislodged and partially lodged maize crop (Figures 10 and 11). The dislodged crop variety had mean grain yield of $7.0 \mathrm{Mg} \mathrm{ha}^{-1}$, whereas the mean grain yield of lodged crop was $3.45 \mathrm{Mg} \mathrm{ha}^{-1}$. The combine harvester with both headers during field operation is shown in Figure 12.

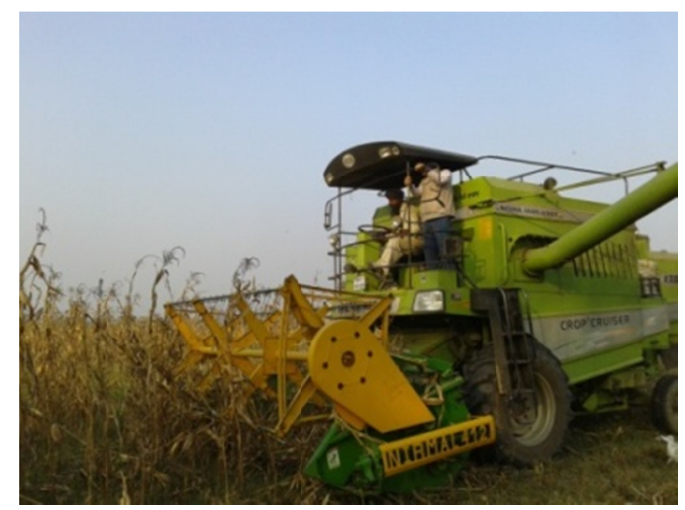

Figure 10. A view of lodged maize harvesting with combine equipped with cutter bar type maize header

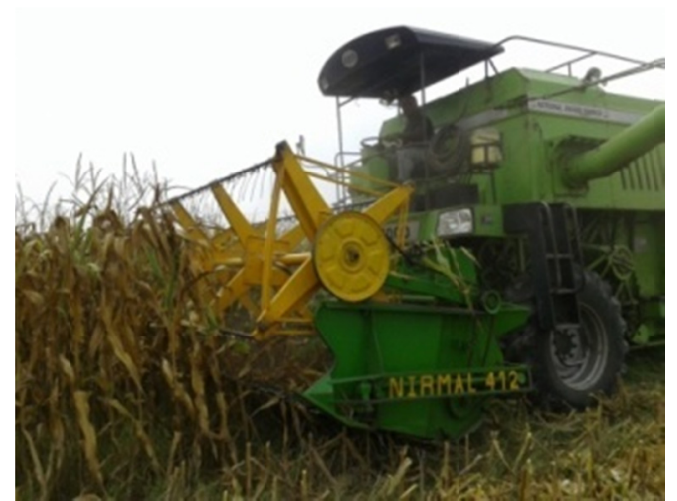

Figure 11. A view of dislodged maize harvesting with combine equipped with cutter type maize header 

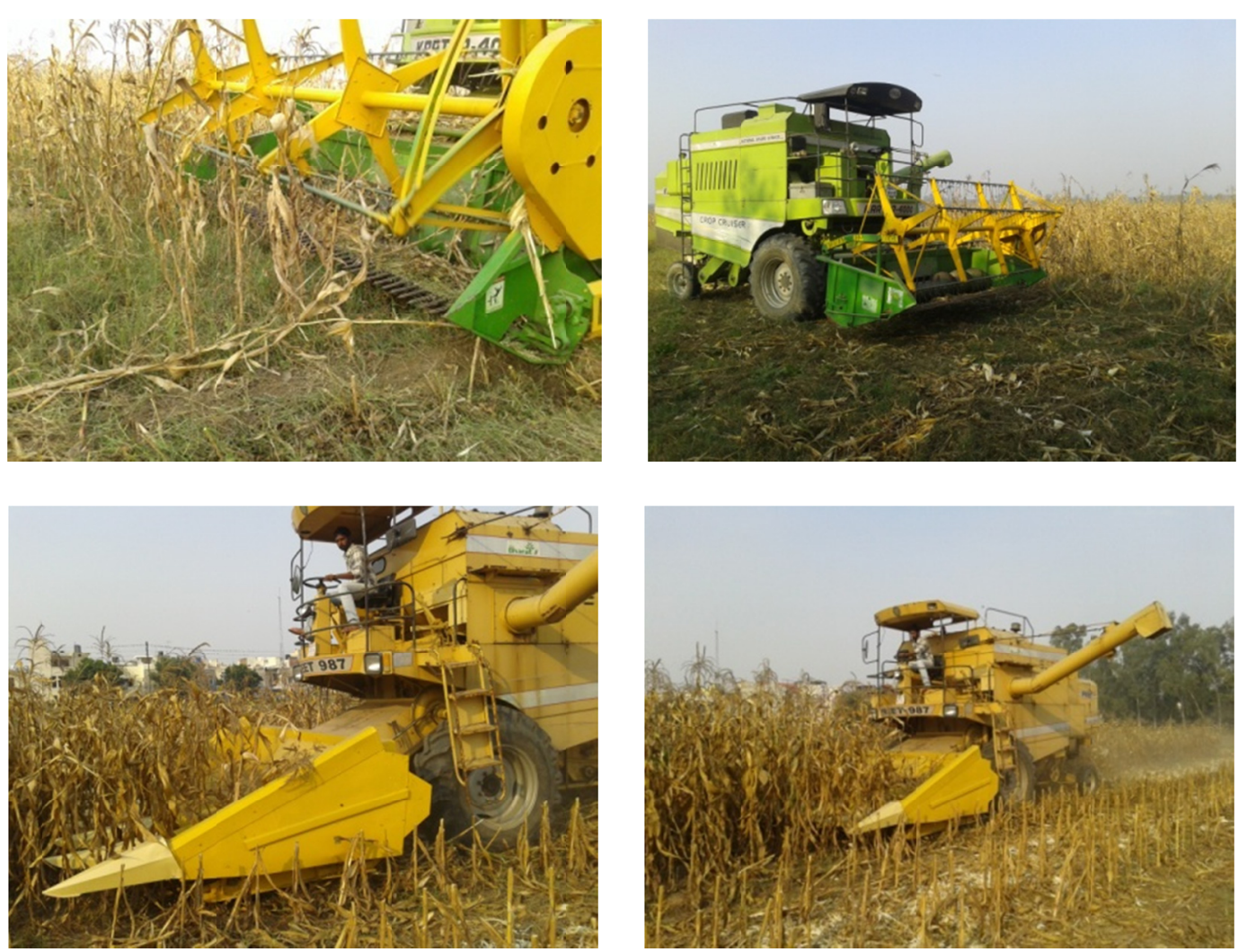

Figure 12. Another view of cutter bar and snap roll maize header during field operation

Table 7. Pre-harvest losses for maize crop

\begin{tabular}{|c|c|c|c|c|}
\hline \multicolumn{5}{|c|}{ Pre-harvest loss for maize crop (\%) } \\
\hline \multirow{5}{*}{ Cutter bar Type } & & 1 & 2 & 3 \\
\hline & Pre-harvest collected grains wt. per ha $(\mathrm{kg})$ & 84.87 & 164.91 & 134.21 \\
\hline & Total grain weight per ha $(\mathrm{kg})$ & 3450 & 3450 & 3450 \\
\hline & Pre-harvest Loss (\%) & 2.46 & 4.78 & 3.89 \\
\hline & Mean \pm S.E & $3.71 \pm$ & & \\
\hline
\end{tabular}

Table 8. Operational parameters for cutter bar type maize combine

\begin{tabular}{|c|c|c|c|c|c|}
\hline \multirow{2}{*}{ Crop and operational parameters } & \multicolumn{2}{|c|}{ Dislodged crop } & \multicolumn{2}{|c|}{ Lodged crop } & \multirow{2}{*}{$\mathrm{CD}(5 \%)$} \\
\hline & Range & Mean \pm S.E. & Range & Mean \pm S.E. & \\
\hline Maize crop m.c. (\% w.b.) & $13.67-14.23$ & 13.97 & $13.67-14.23$ & 13.97 & - \\
\hline Gear used & $1^{\text {st }}$ low- $1^{\text {st }}$ medium & $1^{\text {st }}$ low- $1^{\text {st }}$ medium & $1^{\text {st }}$ low- $1^{\text {st }}$ medium & $1^{\text {st }}$ low- $1^{\text {st }}$ medium & - \\
\hline Engine rpm & $1600-1700$ & - & $1600-1700$ & - & - \\
\hline Forward speed, $\mathrm{km} / \mathrm{hr}$ & $2.10-2.50$ & $2.33 \pm 0.09$ & $2.10-2.45$ & $2.28 \pm 0.07$ & NS \\
\hline Width of cut, $\mathrm{m}$ & 3.65 & 3.65 & 3.65 & 3.65 & - \\
\hline Field capacity, ha/h & $0.32-0.40$ & $0.36 \pm 0.02$ & $0.44-0.53$ & $0.48 \pm 0.02$ & 0.0992558 \\
\hline Fuel consumption, $1 / \mathrm{h}$ & $8.0-11.0$ & $11.25 \pm 0.35$ & $8.0-9.0$ & $8.30 \pm 0.07$ & 1.32605 \\
\hline Fuel consumption, 1/ha & $20.0-27.5$ & $28.12 \pm 0.28$ & $15.70-18.45$ & $17.51 \pm 0.70$ & 2.73732 \\
\hline Height of cut, $\mathrm{m}$ & $0.32-0.45$ & 0.36 & Close to ground & - & \\
\hline Threshing cylinder rpm & $600-700$ & - & $600-700$ & - & - \\
\hline Reel/snap roll rpm & $35-40$ & - & $40-42$ & - & - \\
\hline
\end{tabular}

The view of field after combine operation is shown in Figure 13 and various parameters measured are shown in Table 8. 

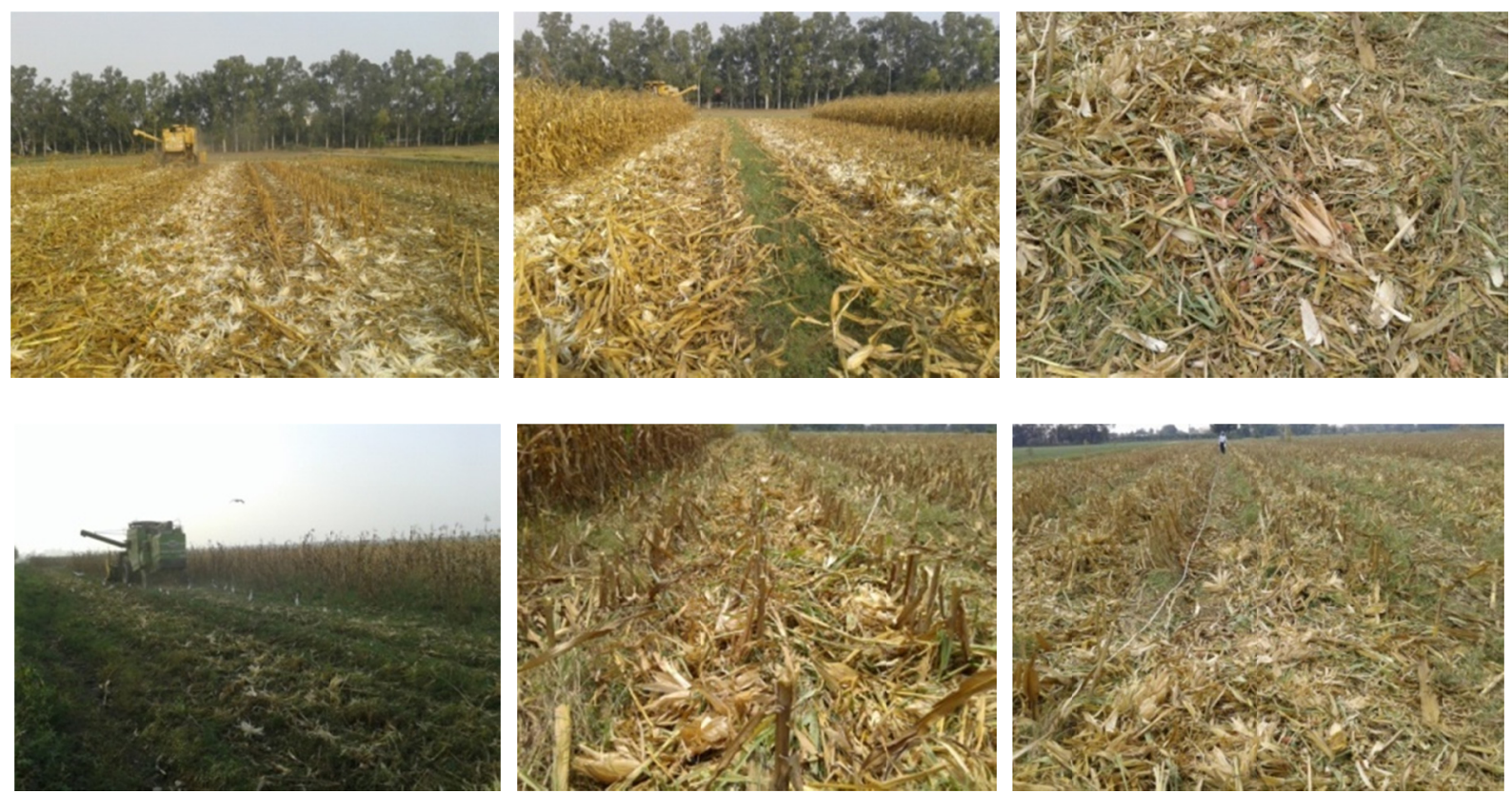

Figure 13. A view of field after the combine harvester operation and forward speed measurement

The height of cut varied between $0.32-0.45 \mathrm{~m}$ in case of dislodged crop. In case of lodged crop, header was kept near the ground. The fuel consumption was higher in dislodged crop (28.12 1/ha) as compared to the lodged crop $(17.51 \mathrm{l} / \mathrm{ha})$. The reason for higher fuel consumption was continuous maize stalk feeding to combine in dislodged crop. Due to this reason, the mean field capacity was also higher $(0.48 \mathrm{ha} / \mathrm{h})$ in lodged crop. The thresher rpm and reel rpm for dislodged crop varied between 600-700 and 35-40 respectively as shown in Table 6 . The reel rpm were kept higher in lodged crop so as to pick the maize stalks.

The mean header ear loss was $8.05 \%$ in dislodged crop, whereas it was $23.68 \%$ in lodged crop (Table 9). Though the cutter bar type maize header was adjusted to nearly horizontal position, yet the lodged crop was not picked completely. Cutter bar header passed over fully lodged crop without picking the cobs, which lead to a higher gathering losses. Cutter bar header managed to pick cobs from those plants which though lodged yet had cobs positioned at some height from ground. The cylinder losses were bit higher $(2.81 \%)$ in dislodged crop as compared to lodged crop $(1.60 \%)$. The higher cylinder loss in dislodged crop may be attributed to the fact as though the height was adjusted between $0.32-.45 \mathrm{~m}$ still due to continuous feeding of non grain matter as compared with lodged crop. Similar reason could be attributed to higher unthreshed losses in dislodged crop as compared to lodged crop. However, cleaning efficiency was higher $(90.58 \%)$ in dislodged crop and grain damage was more $(8.31 \%)$ in lodged crop. The damage was due to non uniform feeding of crop to threshing cylinder which led to more impacts on cobs and grain damage. The trash content for dislodged and lodged crop were $3.46 \%$ and $2.75 \%$ respectively. However, the effect of position of crop on cleaning efficiency, grain damage and trash content were found to be statistically non significant.

Table 9. Maize grain harvested with cutter bar type maize combine

\begin{tabular}{|c|c|c|c|c|c|c|c|c|c|}
\hline & \multicolumn{4}{|c|}{ Dislodged } & \multicolumn{4}{|c|}{ Lodged } & \multirow{2}{*}{$\mathrm{CD}(5 \%)$} \\
\hline & 1 & 2 & 3 & Mean \pm S.E. & 1 & 2 & 3 & Mean \pm S.E. & \\
\hline Grain yield per ha (kg) & 7000 & 7000 & 7000 & 7000.00 & 3450 & 3450 & 3450 & 3450.00 & $0.358469-05$ \\
\hline Shattered grains weight per ha $(\mathrm{kg})$ & 710.42 & 370.15 & 610.36 & $563.64 \pm 74.48$ & 867.33 & 661.71 & 921.50 & $816.85 \pm 59.71$ & NS \\
\hline Header ear loss $(\%)$ & 10.15 & 5.29 & 8.72 & $8.05 \pm 1.06$ & 25.14 & 19.18 & 26.71 & $23.68 \pm 1.73$ & 7.52263 \\
\hline Unthreshed grains weight per ha $(\mathrm{kg})$ & 200.33 & 188.88 & 200.10 & $196.44 \pm 2.91$ & 66.24 & 70.38 & 29.32 & $55.31 \pm 10.00$ & 37.7158 \\
\hline Cylinder loss (\%) & 2.86 & 2.70 & 2.86 & $2.81 \pm 0.04$ & 1.92 & 2.04 & 0.85 & $1.60 \pm 0.29$ & 1.06138 \\
\hline Cleaning efficiency (\%) & 90.36 & 88.28 & 93.10 & $90.58 \pm 0.97$ & 90.34 & 89.18 & 87.10 & $88.87 \pm 0.68$ & NS \\
\hline Grain damage (\%) & 5.72 & 7.42 & 4.70 & $5.95 \pm 0.57$ & 7.62 & 8.12 & 9.20 & $8.31 \pm 0.34$ & NS \\
\hline Trash content $(\%)$ & 3.90 & 4.28 & 2.19 & $3.46 \pm 0.49$ & 1.99 & 2.65 & 3.62 & $2.75 \pm 0.33$ & NS \\
\hline
\end{tabular}


The performance of snap roll header was compared with cutter bar header and operational parameters were measured for both and are shown in Table 10.

Table 10. Operational parameters for cutter bar and snap roll type maize header

\begin{tabular}{|c|c|c|c|c|}
\hline & \multicolumn{2}{|c|}{ Cutter bar type header } & \multicolumn{2}{|c|}{ Snap roll type header } \\
\hline & Range & Mean & Range & Mean \\
\hline Forward speed , km/hr & $2.10-2.50$ & 2.33 & $1.50-1.70$ & 1.60 \\
\hline Width of cut, $\mathrm{m}$ & 3.65 & 3.65 & 3.60 & 3.60 \\
\hline Field capacity, ha/h & $0.32-0.40$ & 0.36 & $0.20-0.50$ & 0.28 \\
\hline Fuel consumption, $1 / \mathrm{h}$ & $8-11$ & 11.25 & $7-10$ & 8.50 \\
\hline Fuel consumption, $1 /$ ha & $25.00-27.50$ & 31.25 & $20-35$ & 30.35 \\
\hline Height of cut, $\mathrm{m}$ & $0.32-0.45$ & 0.36 & $0.40-0.45$ & 0.42 \\
\hline Threshing cylinder rpm & $600-700$ & - & $600-700$ & - \\
\hline Reel/snap roll rpm & $35-40$ & - & $450-500$ & - \\
\hline
\end{tabular}

The performance of snap roll and cutter bar header with maize combine was also done and are shown in Tables 11 and 12 . Total losses with snap roll header were higher as $15.06 \%$ and lower for cutter bar as $10.85 \%$. The brokens were higher for cutter bar as 5.94 and lower for snap roll as $3.45 \%$. The trash content was $3.45 \%$ for cutter bar header and $2.24 \%$ for snap roll header. The higher trash and broken for cutter bar may be attributed to higher non grain portion as compared to cutter bar header.

Table 11. Quality of maize grain harvested with cutter bar and snap roll maize header.

\begin{tabular}{|c|c|c|c|c|c|c|c|c|c|}
\hline \multirow{2}{*}{$\begin{array}{l}\text { Maize grain threshing } \\
\text { quality parameters }\end{array}$} & \multicolumn{4}{|c|}{ Cutter bar Type header } & \multicolumn{4}{|c|}{ Snap Roll Type header } & \multirow{2}{*}{ CD (5\%) } \\
\hline & 1 & 2 & 3 & Mean \pm S.E. & 1 & 2 & 3 & Mean \pm S.E. & \\
\hline Cleaning Efficiency (\%) & 90.36 & 88.28 & 93.10 & $90.58 \pm 1.50$ & 94.85 & 94.76 & 94.09 & $94.76 \pm 0.24$ & 3.93194 \\
\hline Broken loss $(\%)$ & 5.72 & 7.42 & 4.70 & $5.94 \pm 0.70$ & 3.05 & 2.68 & 3.26 & $3.00 \pm 0.17$ & 2.25258 \\
\hline Trash content $(\%)$ & 3.90 & 4.28 & 2.19 & $3.45 \pm 0.64$ & 2.41 & 2.45 & 1.87 & $2.24 \pm 0.19$ & NS \\
\hline
\end{tabular}

Table 12. Total field losses with cutter bar and snap roll maize header

\begin{tabular}{|c|c|c|c|c|c|c|c|c|c|}
\hline \multirow{2}{*}{ Header and cylinder losses } & \multicolumn{4}{|c|}{ Cutter bar Type header } & \multicolumn{4}{|c|}{ Snap Roll Type } & \multirow{2}{*}{ CD (5\%) } \\
\hline & 1 & 2 & 3 & Mean \pm S.E. & 1 & 2 & 3 & Mean \pm S.E. & \\
\hline Total weight of lost grains per ha $(\mathrm{kg})$ & 910.33 & 558.88 & 810.00 & 759.74 & 1373.33 & 813.34 & 976.67 & 1054.34 & - \\
\hline Total weight of grains per ha $(\mathrm{kg})$ & 7000 & 7000 & 7000 & 7000 & 7000 & 7000 & 7000 & 7000 & - \\
\hline Total Loss $(\%)$ & 13.00 & 7.98 & 11.57 & $10.85 \pm 1.49$ & 19.61 & 11.61 & 13.95 & $15.06 \pm 2.37$ & NS \\
\hline
\end{tabular}

The economic analysis of cutter bar header was done with snap roll type maize header and conventional maize dehusker cum sheller, which is shown in Table 13. The saving in cost and time with cutter bar type header was $77.77 \%$ and $85.42 \%$ as compared to maize dehusker cum sheller. The saving in cost and time with snap roll maize header was $71.72 \%$ and $83.68 \%$ as compared to maize dehusker cum sheller. 
Table 13. Economics of cutter bar type maize header, snap roll header and maize dehusker cum sheller

\begin{tabular}{|c|c|c|c|c|c|}
\hline & Tractor $45-50 \mathrm{HP}$ & \multicolumn{2}{|c|}{ Maize dehusker cum sheller } & snap roll & cutter bar \\
\hline New cost, $\mathrm{P}$ & 550000 & \multicolumn{2}{|l|}{120000} & 500000 & 180000 \\
\hline Life (yrs), L & 15 & \multicolumn{2}{|l|}{10} & 10 & 10 \\
\hline Avg. use/yr (h) & 700 & \multicolumn{2}{|l|}{200} & 700 & 300 \\
\hline Rate of interest (\%), i & 12 & \multicolumn{2}{|l|}{12} & 12 & 12 \\
\hline Field capacity, ha/h & Of implement & \multicolumn{2}{|l|}{0.17} & 0.28 & 0.36 \\
\hline Salvage value, $\mathrm{S}=10 \%$ of $\mathrm{P}$ & 55000 & \multicolumn{2}{|l|}{12000} & 50000 & 18000 \\
\hline \multicolumn{6}{|l|}{ Annual Fixed Charges } \\
\hline Depreciation (Rs/yr) & 33000 & \multicolumn{2}{|l|}{10800} & 45000 & 16200 \\
\hline Interest cost (Rs/yr) & 36300 & \multicolumn{2}{|l|}{7920} & 33000 & 11880 \\
\hline Taxes, insurance and shelter $(\mathrm{Rs} / \mathrm{yr})=2 \%$ of $\mathrm{P}$ & 11000 & \multicolumn{2}{|l|}{2400} & 10000 & 3600 \\
\hline Total fixed costs (Rs/yr) & 80300 & \multicolumn{2}{|l|}{21120} & 88000 & 31680 \\
\hline Total fixed costs $(\mathrm{Rs} / \mathrm{h})$ & 114.71 & \multicolumn{2}{|l|}{105.60} & 125.71 & 105.60 \\
\hline Variable Costs & & & & & \\
\hline Fuel required $(1 / h)$ (depend on implement & 0 & 8 & & 10 & 11.25 \\
\hline Labour required with machine & 1 & 1 & & 5 & 5 \\
\hline Labour cost $(\mathrm{Rs} / \mathrm{h})$ & 40 & 31.25 & & 31.25 & 20 \\
\hline Repair \& maintenance (Rs/h) & 39.29 & 30.00 & & 35.71 & 30.00 \\
\hline Fuel cost $(\mathrm{Rs} / \mathrm{h})$ at $\mathrm{rs} 68 / 1$ & 0 & 544 & & 680 & 765 \\
\hline Cost of lubricants $(\mathrm{Rs} / \mathrm{h})=20 \%$ of fuel cost & 0 & 108.8 & & 136 & 153 \\
\hline Labor cost $(\mathrm{Rs} / \mathrm{h})$ & 40 & 31.25 & & 156.25 & 100 \\
\hline Total variable cost $(\mathrm{Rs} / \mathrm{h})$ & 79.29 & 714.05 & & 1007.96 & 1048.00 \\
\hline Total Costs & & & & & \\
\hline Total cost (fixed + variable) $(\mathrm{Rs} / \mathrm{h})$ & 194.00 & 819.65 & & 1133.68 & 1153.60 \\
\hline Total cost, Rs/ha including tractor & & 5962.6 & & 4741.71 & 3743.33 \\
\hline Labour required off machine operation, man $(\mathrm{h} / \mathrm{ha})$ & & 250 & & 10 & 10 \\
\hline Grand Total machine Cost, Rs/ha & & 13775. & & 5054.21 & 3943.33 \\
\hline Particulars & Cutter bar mai & header & Snap roll maize header & Maize deh & r cum sheller \\
\hline New cost $\left(\right.$ Rs unit $\left.{ }^{-1}\right), P$ & 180000 & & 500000 & 120000 & \\
\hline USD $\left(\$\right.$ unit $\left.^{-1}\right)$ & 2803.55 & & 7787.63 & 1869.03 & \\
\hline Cost of operation, Rs/ha & 3943.33 & & 5054.21 & 13775.15 & \\
\hline USD\$/ha* & $53.62 \$$ & & $68.73 \$$ & $187.32 \$$ & \\
\hline Field capacity, ha/h & 0.36 & & 0.28 & 0.17 & \\
\hline Man-h involved per ha & 42.00 & & 47.00 & 288.00 & \\
\hline Saving in cost as compared to maize dehusker cum sheller, $\%$ & \% 77.77 & & 71.72 & - & \\
\hline Saving in time as compared to maize dehusker cum sheller, $\%$ & $\% \quad 85.42$ & & 83.68 & - & \\
\hline Saving in cost and time as compared to snap roll header & $21.98,10.64 \%$ & & & & \\
\hline Weight, $\mathrm{kg}$ & 1200 & & 1860 & 815 & \\
\hline Human energy consumption, $\mathrm{MJ} / \mathrm{ha}$ & 82.32 & & 92.12 & 564.48 & \\
\hline Fuel Energy consumption, MJ/ha & 1759.69 & & 2011.07 & 2649.88 & \\
\hline Energy embodied in machinery, MJ/ha & 128.89 & & 256.86 & 556.12 & \\
\hline Energy embodied in machinery, $\mathrm{MJ} / \mathrm{ha}$ & 1970.90 & & 2360.05 & 3770.48 & \\
\hline
\end{tabular}

Note. $* 1 \mathrm{USD}=73.54$ INR.

\section{Summary}

A new type of cutter bar type maize header was designed and developed for harvesting of maize crop which cuts the maize plant from a certain height and feeds plant along with cob to the threshing unit of the combine. Height of cut was adjustable. The maize header was capable of cutting of maize crop irrespective of maize crop row width. The pre-harvest losses varied from $84.87-164.91 \mathrm{~kg} / \mathrm{ha}$. For lodged crops the gathering losses varied from $19.18-26.71 \%$ and for unlodged crops varied from $5.28-10.14 \%$ respectively. The higher gathering losses in lodged crop may be attributed to fact that header could not pick the lodged crop whereas in unlodged crop the header picked cobs from maize plant efficiently. The cylinder losses for unlodged crop varied from $2.8 \%$ and for 
lodged crop were $1.6 \%$. The mean cleaning efficiency for lodged and unlodged maize crop were 88.87 and $90.58 \%$ respectively. The grain damage for lodged and unlodged crop were $8.31 \%$ and $5.94 \%$ respectively. The Trash content for lodged and unlodged crop were 2.75 and $3.45 \%$ respectively. The maize combine performance was satisfactory with cutter bar header for maize crop at $1^{\text {st }}$ low gear, forward speed of $2.10 \mathrm{Km} \cdot \mathrm{h}^{-1}$ and reel rpm of 35. The maize crop residue after harvesting with cutter bar type maize header can be easily chopped and incorporated with disc harrow, rotary tiller etc. The performance of snap roll and cutter bar header with maize combine was also done. Total losses with snap roll header were higher as $15.06 \%$ and lower for cutter bar as $10.85 \%$. The brokens were higher for cutter bar as 5.94 and lower for snap roll as $3.45 \%$. The trash content was $3.45 \%$ for cutter bar header and $2.24 \%$ for snap roll header (Figure 14).

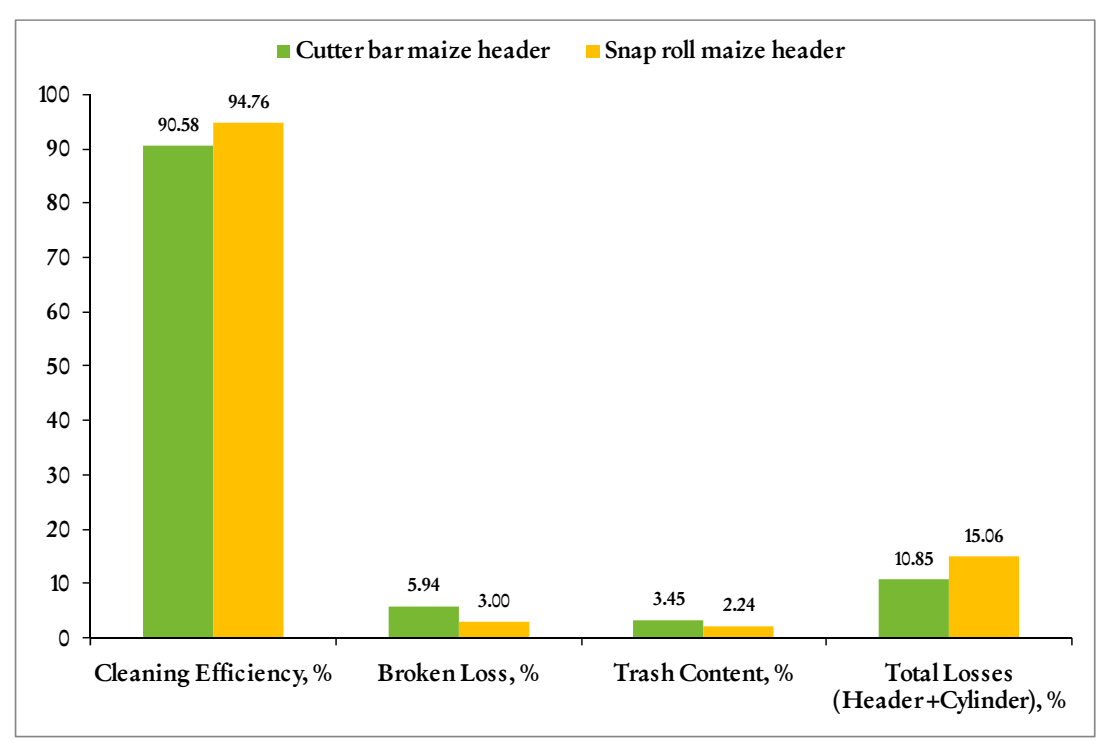

Figure 14. Graphical representation of field losses with combine harvester with cutter bar maize header and snap roll maize header

Undoubtedly header was more effective during turning at headlands as compared to snap roll type header owing to its independence from plant row spacings lacking of which in case of snap roll header causes a lot of gathering losses during turnings at headlands. Similar results were reported by Paulsen et al. (2014) in lodged maize crop. In the present study, $30-40 \%$ maize crop was lodged. Though the cutter bar type maize header was adjusted to nearly horizontal position yet the lodged crop was not picked completely. Cutter bar header passed over fully lodged crop without picking the cobs which lead to higher gathering losses for this header. Cutter bar header managed to pick cobs from those plants which though lodged but having cobs positioned at some height from ground. The lodged crop affects badly the working of any header mechanism during combine harvesting. The operator driving skill, header adjustment during field operation, combine forward speed with respect to reel speed, optimum maize crop moisture content (not too wet nor to dry) are the key factors which are needed to be given due importance before starting harvesting with combine so as to minimize various losses during field operation and better combine harvester performance. Particularly in case of lodged crop the field layout (from where to start) also plays an important role so that driver has an overview in mind how to operate effectively and adjust combine, reel and thresher speed during various sections of field so as to minimize field losses and maximizing the clean grain output. The developed cutter bar header cuts the maize plant from a certain height (adjustable) with minimum losses and feeds plant along with cob to the threshing unit of the combine. The maize header was capable of cutting the maize crop, irrespective of the width of the row and has higher field capacity as compared to snap roll header.

Thus a low cost effective cutter bar maize header was developed which is in the range of small and marginal farmers also and can be operated on custom hiring basis also. Moreover this header owing to its low weight can be operated with low HP combines with low repair and maintenance cost. 


\section{Conclusions}

The performance of snap roll and cutter bar header with maize combine was also done. Total losses with snap roll header were higher as $15.06 \%$ and lower for cutter bar as $10.85 \%$. The brokens were higher for cutter bar as 5.94 and lower for snap roll as $3.45 \%$. The trash content was $3.45 \%$ for cutter bar header and $2.24 \%$ for snap roll header. This new type of developed cutter bar header can be used for harvesting maize crop efficiently and with minimum of losses as compared to snap roll header and maize dehusker cum sheller. Undoubtedly, the header was more effective during turning at headlands as compared to snap roll type header. Since, the header is independent of the width of the row, the gathering losses at the turning are much lower than those acquired in case of snap roll header. Though the cutter bar type maize header was adjusted to nearly horizontal position yet the lodged crop was not picked completely. Cutter bar header passed over fully lodged crop without picking the cobs which lead to higher gathering losses. Cutter bar header managed to pick cobs from those plants which though lodged but had cobs positioned at some height from ground. The operator driving skill, header adjustment during field operation, combine forward speed with respect to reel speed, optimum maize crop moisture content (not too wet nor to dry) are the key factors which are needed to be given due importance during combine harvesting. For minimizing various losses during field operation and better performance, particularly in case of lodged crop, the field layout (from where to start) also plays an important role. Therefore, the operator must have an overview in mind about how to effectively operate and adjust combine, reel and thresher speed during various sections of field thereby ensuring minimum field losses and maximum output.

\section{References}

Abdi, R., \& Jalali, A. (2013). Mathematical model for prediction combine harvester header losses. Int. J. Agric. Crop Sci., 5(5), 549-552.

Behroozi-Lar, M. (1995). Final report of combine harvester research (No. 37). Agricultural Department.

Behroozi-Lar, M., \& Mobli, H. (2006). Engineering principles of agricultural machinery (2nd ed., Chapter 9, pp. 471-512).

Davoodi, M. J. S., \& Houshyar, E. (2010). Evaluation of wheat losses using new Holland combine harvester in Iran. American-Eurasian J. Agric. Environ. Sci., 8(1), 104-108.

Digman, M. (2009). Combine considerations for a wet corn harvest. Madison, WI: University of Wisconsin-Madison.

Hanna, M. (2008). Combine harvesting tips for 2008 harvest. Ames, IA: Iowa State University Extension.

Hanna, M., \& Fossen, L. V. (1990). Profitable corn harvesting. Ames, IA: Iowa State University Extention.

Hassani, H. S., Jafari, A., Mohtasebi, S. S., \& Setayesh, A. M. (2011). Investigation of grain losses of the JD 1165 combine harvester equipped with variable pulley and belt for forward travel. Am. J. Food Technol., 6(4), 314-321. http://doi.org/10.3923/ajft.2011.314.321

Humburg, D. S., Nicolai, R. E., \& Reitsma, K. D. (2009). Best management practices for corn production in South Dakota: Corn grain harvest. Brookings, SD: South Dakota State University.

Kepner, R. A., Bainer, R., \& Barger, E. L. (1978). Principles of farm machinery. Westport, CT: Avi Pub. Co.

King, W. N., Peterson, L., \& Curley, R. G. (1955). Field corn pickers: Tests indicate two operational factors have important effect on field losses. California Agriculture, 9(7), 13-15.

Mansouri, H., \& Minaei, S. (2003). Assessment of machine parameters effect on wheat loss in combine JD 955 (pp. 24-28). First Natl. Conf. Assessing Agricultural Crop Waists, Agricultural Faculty of Tarbiat Modaaress University, Tehran, Iran.

Mazaheri, D. (1997). Final report of future food plan. Islamic Republic of Iran Science, Agricultural Science Department.

Miodragovic, R., \& Djevic, M. (2006). Contemporary combine harvesters in corn harvesting. Annals Fac. Eng. Hunedoara, 4(3), 199-206.

Morvaridi, N., Asoodar, M. A., Khademalhosseini, N., Shamsi, H., Nezhad, M. G., \& Amirpoor, P. (2008). Evaluation of losses on corn combine harvester and introducing an optimum pattern under Khouzistan province climate condition. Proc. 5th Natl. Conf. Agricultural Machinery Engineering and Mechanization. Iran: Ferdowsi University of Mashhad.

Mostofi, M. R., Shaker, M., \& Mahdinia, A. (2011). Investigation and technical comparison of new and 
conventional wheat combines performance for improvement and modification. CIGR J., 13(3), 63-68.

Paulsen, M. R., Kalita, P. K., \& Rausch, K. D. (2015). Postharvest losses due to harvesting operations in developing countries: A review. 2015 ASABE Annual International Meeting, ASABE, St. Joseph, MI. http://doi.org/10.13031/aim.20152176663

Paulsen, M. R., Pinto, F. A. C., de Sena Jr, D. G., Zandonadi, R. S., Ruffato, S., Costa, A. G., .. Danao, M.-G. C. (2014). Measurement of combine losses for corn and soybeans in Brazil. Appl. Eng. Agric., 30(6), 841-855. http://doi.org/10.13031/aea.30.10360

Pishgar-Komleh, S. H., Keyhani, A., Mostofi-Sarkari, M. R., \& Jafari, A. (2012). Predicting the relationship between grain-combine travel, cylinder speed and harvesting losses by applying artificial neural networks. Int. J. Appl. Sci. Eng. Res., 1(3), 405-414. http://doi.org/10.6088/ijaser.0020101041

Pužauskas, E., Steponavičius, D., Jotautienè, E., Petkevičius, S., \& Kemzūraite, A. (2016). Substantiation of concave crossbars shape for corn ears threshing. Mechanika, 22(6), 553-561. http://doi.org/10.5755/ j01.mech.22.6.16370

Qarnar-uz-Zaman, A., Chaudhary, D., \& Asghar Rana, M. (1992). Wheat harvesting losses in combining as effected by machine and crop parameters. Pak. J. Agri. Sei., 29(1), 1-4.

Quick, G. R. (2003). Combine sweet spot: Integrating harvested yield, grain damage and losses. Proc. Int. Conf. Crop Harvesting and Processing. St. Joseph, MI: ASABE. http://doi.org/10.13031/2013.15211

Rahimi, H. A., \& Khosravani, A. (2003). Assessment of decreasing wheat losses methods on harvesting stages in fars province (pp. 45-51). Abstract of paper on First Natl. Conf. Assessing Agricultural Crops Waists, Agricultural Faculty of Tarbiat Modaress University, Tehran, Iran.

Sumner, P. E., \& Williams, E. J. (2009). Measuring field losses from grain combines. Athens, GA: The University of Georgia Cooperative Extension.

Zareei, S., \& Abdollahpour, S. (2016). Modeling the optimal factors affecting combine harvester header losses. CIGR J., 18(2), 1-6.

\section{Copyrights}

Copyright for this article is retained by the author(s), with first publication rights granted to the journal.

This is an open-access article distributed under the terms and conditions of the Creative Commons Attribution license (http://creativecommons.org/licenses/by/4.0/). 